\title{
FISH ASSEMBLAGES OF A SHALLOW MEDITERRANEAN LAGOON (NADOR, MOROCCO): AN ANALYSIS BASED ON SPECIES AND FUNCTIONAL GUILDS
}

\author{
Sakina JAAFOUR ${ }^{1,2}$, Ahmed YAHYAOUI ${ }^{1}$, Abderrahim SADAK ${ }^{1}$, Mahmoud BACHA ${ }^{2}$, \\ and Rachid AMARA ${ }^{2 *}$ \\ ${ }^{1}$ Mohammed V University of Agdal, Laboratory of Zoology and General Biology, Rabat, Morocco \\ ${ }^{2}$ University of Littoral Côte d'Opale, Laboratory of Oceanography and Geosciences, Wimereux, France
}

\begin{abstract}
Jaafour S., Yahyaoui A., Sadak A., Bacha M., Amara R. 2015. Fish assemblages of a shallow Mediterranean lagoon (Nador, Morocco): An analysis based on species and functional guilds. Acta Ichthyol. Piscat. 45 (2): 115-124.
\end{abstract}

\begin{abstract}
Background. Due to their location between the continent and the sea and their shallow depths, lagoons play an important ecological role in coastal ecosystems by providing a selection of habitat types for many species, functioning as nursery areas and feeding grounds for marine opportunistic fishes. The fish fauna of the Nador Lagoon (NE Morocco), as in the majority of southern Mediterranean lagoons, has been insufficiently studied, even though the lagoon itself supports important commercial fisheries. The presently reported study investigated the spatial and seasonal uses of shallow habitats for fish fauna in the Nador Lagoon.

Materials and methods. Sampling was done using a beach seine net at six stations covering almost entire lagoon and representing habitats differing in many parameters such as the distance from the inlet, bottom sediment characteristics, presence of macroalgae, etc. The fish abundance was standardized as catch per unit effort (CPUE) and the fish community was analysed both in terms of its taxonomic and functional composition (by making use of both ecological and dietary preference guilds).

Results. A total of 2872 individuals, representing 15 species from 12 families, was collected during the four seasons. Only six species were always present in all seasons. Fish abundance peaked in spring and the species diversity was higher in spring and summer. The fish assemblage was largely dominated in terms of ecological guild by the resident and benthivorous species. Spatial and seasonal fish assemblages differed both in terms of fish abundance and diversity and also in terms of functional guilds composition. In autumn, the fish assemblage was dominated by the marine juvenile migrants whereas in winter, spring, and summer, resident species were the most abundant.

Conclusion. The combination of taxonomic and functional characteristics of the fish assemblages, determined in the presently reported study, may contribute to a better understanding of the ecological networks of the Nador Lagoon, thus providing useful data for its conservation and management.
\end{abstract}

Keywords: fish, spatio-temporal assemblages, beach seine, lagoon, Nador, Morocco

\section{INTRODUCTION}

Due to their location between the continent and the sea and their limited depths, lagoons are among the most productive ecosystems, particularly in the Mediterranean region (Crivelli and Ximenes 1992). They play an important ecological role in coastal ecosystems by providing a selection of habitat types for many species, functioning as nursery areas and feeding grounds for marine opportunistic fishes (Franco et al. 2008, Maci and Basset 2009, Pérez-Ruzafa and Marcos 2012). Many coastal lagoons support important fisheries, and some of them maintain intensive and extensive aquaculture operations (Pérez-Ruzafa and Marcos 2012).
The functional roles of coastal lagoons in relation to fish have been extensively investigated in the northern part of the Mediterranean Sea (Dumay et al. 2004, Poizat et al. 2004, Malavasi et al. 2004, Franco et al. 2006, 2008, Maci and Basset 2009) but few studies were done in the southern part (Bouchereau et al. 2000, Kraïem et al. 2009, Sellami et al. 2010). The recent study on Atlanto-Mediterranean lagoons by Pérez-Ruzafa et al. (2011) highlighted the presence of a north-south gradient in research effort or knowledge about the role of coastal lagoon for fish, with few data from the southern Mediterranean. This is a major handicap at the moment, when ways of better managing 
or even restoring certain Mediterranean lagoons are being discussed. Hence, there is a need for more information on the role and functioning of coastal lagoons in terms of fish requirements.

The Nador Lagoon, also known as the "Sebkha Bou-Areg" or "Mar Chica" (the small sea), is the second largest lagoon complex in northern Africa $\left(115 \mathrm{~km}^{2}\right)$ and the broadest paralic environment of Morocco. Its importance consists not only in its ecological value (RAMSAR site) but also in its socio-economic role. The fish fauna of the Nador Lagoon is not well known (Bouchereau et al. 2000), although the lagoon itself maintains a diverse fish community and supports important commercial fisheries (Kada et al. 2009). Indeed, the lagoon supports an important fishing activity carried out by 390 small fishing boats spread over 12 sites (Malouli Idrissi et al. unpublished*). This lagoon provides important opportunities for the development of the region, where many interests may conflict, from fisheries to tourism, and from aquaculture to harbour facilities or urban development. However, the ecological functioning and importance of this lagoon for fish has still not been properly investigated.

The main objective of this study was to describe the fish assemblages regarding their taxonomic and functional compositions and to assess their spatial and seasonal changes. The joint taxonomic and functional description of the fish assemblages will hopefully permit a better understanding of their functioning, thus providing useful data regarding the conservation and management of the lagoon systems.

\section{MATERIALS AND METHODS}

Study area and sampling. The Nador Lagoon is located in the north-eastern part of the Moroccan Mediterranean coast (Fig. 1). The lagoon has an oval shape, is quite regular, and has a single inlet (the Boccana). The length of its major axis is about $23 \mathrm{~km}$, while the minor one is about $7 \mathrm{~km}$. Its depth averages $4.8 \mathrm{~m}$ with a maximum of $8 \mathrm{~m}$. The internal hydrodynamics of the Nador Lagoon depends on three types of hydrological resources:

- The marine waters passing through the artificial inlet, which are always dominant;

- The hydrogeological contributions from two aquifersGareb, located in southern Selouane, and Bou Areg, situated near the southern margin of the lagoon; and

- The surface water inputs, with periodic flows of 10 small streams ("oueds") (Ruiz et al. 2006).

In the lagoon, these individual inflows are managed by internal currents, which have a clockwise direction from the artificial inlet toward the NW coast, moving about the internal face of the sandy spit and the internal lagoon margin (Guelorget et al. 1987). The bottom sediments of the continental margin consist mainly of black silts, whereas the rest of the lagoon is dominated by very fine to medium sands (Ruiz et al. 2006). The macrophytes recorded in the lagoon, were most frequently represented by seagrasses: Cymodocea nodosa (Cymodoceaceae) and Zostera noltei (Zosteraceae) and the chlorophyte, Caulerpa prolifera
(Caulerpaceae). Generally, the invasive macroalgae, $C$. prolifera, covers most of the bottom, except the central part, which is devoid of macrophytes, restricting the seaweed $C$. nodosa to small bands in the shallowest areas surrounding the lagoon (El Madani et al. 2011).

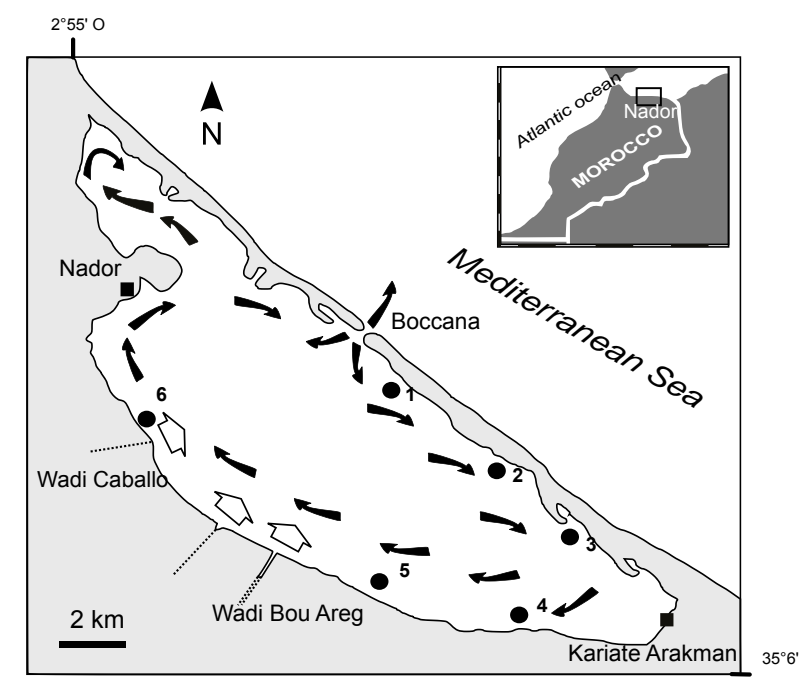

Fig. 1. The Nador Lagoon and location of the six sampling stations; Black arrows indicate the clockwise direction of the water flow in the lagoon; White arrows indicate the main freshwater inflows

Sampling was done in the shallow waters at six stations (Fig. 1), covering almost all the lagoon and representing habitats differing in many parameters such as the distance from the inlet, bottom sediment characteristics, presence of macroalgae, etc. Sampling was done during daylight hours using a beach seine net $(14 \mathrm{~m}$ length $\times 2 \mathrm{~m}$ height, with a mesh size of $3 \mathrm{~mm}$ ). The seine net was considered appropriate for catching small $(<100 \mathrm{~mm}$ TL) fishes, which abound in shallow estuarine habitats (Elliott and Hemingway 2002, Guest et al. 2003). At each station, two replicate collections were made. Samples were collected once, during autumn (2012) and winter, spring, and summer (2013).

After each sampling, fish were preserved in plastic bags and transported in an isothermal ice container to the laboratory. All fishes were identified to species level, counted, measured (total length TL, $\mathrm{cm}$ ) to the nearest $\mathrm{cm}$ and weighed (total weight $W, \mathrm{~g}$ ) with a precision of 0.1 g. For each station, the numbers of fish caught per haul were expressed as catch per unit effort (CPUE; No. of individuals per sample), which represents the number of fish caught in a single seine haul in each season.

Data analysis. Total fish abundance (number of individuals) was calculated for each sampling station in each season, as well as the mean fish abundance in each season. Species richness (the total number of species caught in each station or during each season) and Shannon-Wiener diversity indices were calculated (Krebs 1999). Fish species were allocated to functional groups according to their habitat use and feeding modes, following the classification 
of Franco et al. (2008). Fish species were also allocated to functional groups according to their habitat use and feeding modes, following the classification of Franco et al. $(2008,2011)$ and information from FishBase (Froese and Pauly 2014). Three ecological groups were sampled in the shallow habitats of the Nador Lagoon: residents (R), marine seasonal migrants (MM), and marine juvenile migrants (MJ). Six feeding groups were identified: omnivorous (OV); strictly benthivorous (BV), detritivorous, (DV); hyperbenthos fish feeders (HZ), fish showing an ontogenetic change in feeding preference from hyperbenthos zooplankton to hyperbenthos (HZ, HP), fish showing an ontogenetic change in feeding preference from microbenthos to hyperbenthos (Bmi, HP).

Multivariate statistics (PRIMER software package, Version 6.1.9, Clarke and Warwick 2001) were used in order to investigate any changes in the assemblage structure. For spatial analysis, a Bray-Curtis similarity coefficient, applied to on the abundance data was calculated in order to compute a similarity matrix, from which the non-metric multidimensional scaling (MDS) ordination was generated (Kruskal and Wish 1978).

Factorial correspondence analysis (FCA) was performed using fish abundance and ecological guild data to investigate the pattern of species assemblage among seasons. FCA was performed using XLSTAT software. The typifying species for each group were determined using the SIMPER. This procedure determines the average contribution of each species to the similarity and dissimilarity between groups per combinations and was used to perform SIMPER and nMDS.

\section{RESULTS}

A total of 2872 individuals was collected during the four seasons, representing 15 species from 12 families (Table 1). Only six species were always present in all seasons. The majority of the fish caught were juveniles; the fish size varied from $2.80 \pm 0.53 \mathrm{~cm}$ - for Pomatoschistus marmoratus (Risso, 1810) - to $13.03 \pm 5.08 \mathrm{~cm}$-for Hyporhamphus picarti (Valenciennes, 1847).

The fish assemblage was largely dominated in terms of ecological guild by the resident species (R: 8 species representing 375 individuals, $68.43 \%$ of the total catches), followed by marine migrant (MM: 5 species representing 100 individuals, $8.14 \%$ of the total catches), and marine juvenile migrants (MJ: 2 species representing 128 individuals, $23.42 \%$ of the total catches) (Table. 1). Among the feeding guilds, benthivorous species (BV) were dominant in the fish assemblage in terms of both species number $(8$ species) and abundance (313 individuals, 57.14\% of the total catches).

Spatial and seasonal fish assemblages differed both in terms of fish abundance and diversity and also in term of functional guilds composition. Spatial analysis revealed three groups of stations (Fig. 2):

- Group 1 (stations 1, 2, and 3)-influenced by its proximity to the marine inlet and characterized mainly by sandy or muddy sand bottom;

Table 1

Selected characteristics of fish species sampled at different season in the Nador Lagoon, Morocco

\begin{tabular}{|c|c|c|c|c|c|c|c|c|c|c|c|c|c|c|}
\hline \multirow[b]{2}{*}{ Species } & \multirow{2}{*}{$\begin{array}{c}\text { Habi- } \\
\text { tat } \\
\text { use }\end{array}$} & \multirow{2}{*}{$\begin{array}{c}\text { Feeding } \\
\text { mode }\end{array}$} & \multicolumn{3}{|c|}{ Autumn } & \multicolumn{3}{|c|}{ Winter } & \multicolumn{3}{|c|}{ Spring } & \multicolumn{3}{|c|}{ Summer } \\
\hline & & & $\mathrm{AB}$ & $\begin{array}{c}\mathrm{TL} \\
{[\mathrm{cm}]}\end{array}$ & $\begin{array}{l}\mathrm{OC} \\
{[\%]}\end{array}$ & $\mathrm{AB}$ & $\begin{array}{c}\mathrm{TL} \\
{[\mathrm{cm}]}\end{array}$ & $\begin{array}{c}\mathrm{OC} \\
{[\%]}\end{array}$ & $\mathrm{AB}$ & $\begin{array}{c}\mathrm{TL} \\
{[\mathrm{cm}]}\end{array}$ & [\%] & $\mathrm{AB}$ & $\begin{array}{c}\mathrm{TL} \\
{[\mathrm{cm}]}\end{array}$ & $\begin{array}{c}\mathrm{OC} \\
{[\%]}\end{array}$ \\
\hline . & MJ & $\mathrm{HZ}$, & 40.67 & 5.07 & 50.00 & 33 & 5.95 & 16.67 & .25 & 6.64 & 75.00 & 1.50 & 4.28 & 100.0 \\
\hline alaria pavo & $\mathrm{R}$ & & 6.00 & 6.24 & 50.00 & 0.00 & - & 0.00 & & 6.90 & 100.00 & .50 & 6.72 & 75.00 \\
\hline allionymus risso & $\mathrm{R}$ & & 00 & - & 0 & 00 & - & 00 & & 7.10 & 25.00 & 25 & 2.90 & 2500 \\
\hline & $\mathrm{R}$ & & & - & 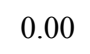 & & 3.33 & 16.67 & & 2.80 & 100.00 & & 3.27 & 0 \\
\hline iiger & $\mathrm{R}$ & III, ПI & 10.33 & 6.88 & 83.33 & 14.67 & 4.55 & 100.00 & 1.75 & 7.44 & 50.00 & 4.50 & 7.32 & 75.00 \\
\hline Iyporhamphu & MJ & BV & 45.33 & 6.74 & 66.67 & 0.00 & - & 000 & 000 & - & 000 & 7.25 & 13.03 & 250 \\
\hline & $\Lambda$ & & & - & 0.00 & 0.00 & - & 0.00 & 0.00 & - & 0.00 & .75 & 7.80 & 50.0 \\
\hline ymp & $\mathrm{R}$ & & 0.00 & - & 0 & 00 & - & 000 & 50 & 6.10 & 75.00 & 0 & 0.00 & 0.00 \\
\hline Dicel & M & & 0.17 & 14.80 & 16.67 & 0.00 & - & 0.00 & 0.00 & - & 0.00 & 0.00 & 0.00 & 0.00 \\
\hline & & & 13.33 & 9.33 & 66.00 & 3.95 & 83.33 & 1.25 & 8.10 & 50.00 & 0.00 & 0.00 & 0.00 & 0.00 \\
\hline & & & & - & 0.00 & 0.00 & - & 0.00 & 0.00 & - & 0.00 & 0.50 & 9.15 & 50.0 \\
\hline Solea solea & & & 0.00 & - & 0.00 & . & - & 0.00 & 0.25 & 16.50 & 25.00 & 0.75 & 6.63 & 75.00 \\
\hline Diplodus puntazzo & MM & $\mathrm{OV}$ & 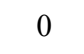 & - & 0.00 & 8.83 & 2.84 & 66.67 & 7.25 & 4.67 & 75.00 & 1.50 & 5.31 & 50.00 \\
\hline Syngnathus typhle & $\mathrm{R}$ & $\mathrm{HZ}$ & 8.00 & 10.63 & 33.33 & 6.17 & 10.67 & 83.33 & 34.25 & 10.22 & 100.00 & 24.00 & 13.02 & 100.0 \\
\hline Syngnathus abaster & $\mathrm{R}$ & $\mathrm{BV}$ & 0.67 & 5.17 & 16.67 & 1.33 & 8.41 & 33.33 & 35.50 & 9.25 & 100.00 & 26.00 & 8.94 & 100.0 \\
\hline
\end{tabular}

$\mathrm{AB}=$ abundance (catch per unit effort), $\mathrm{TL}=$ total length, $\mathrm{OC}=$ occurrence, $\mathrm{MJ}=$ marine juvenile migrants, $\mathrm{R}=$ resident, $\mathrm{MM}=\mathrm{marine}$ seasonal migrants, HZ, HP = fish showing an ontogenetic change in feeding preference from hyperbenthos zooplankton to hyperbenthos, $\mathrm{OV}=$ omnivorous, $\mathrm{BV}=$ benthivorous, Bmi, HP = fish showing an ontogenetic change in feeding preference from microbenthos to hyperbenthos, $\mathrm{DV}=$ detritivorous, $\mathrm{HZ}=$ hyperbenthos fish feeders . 

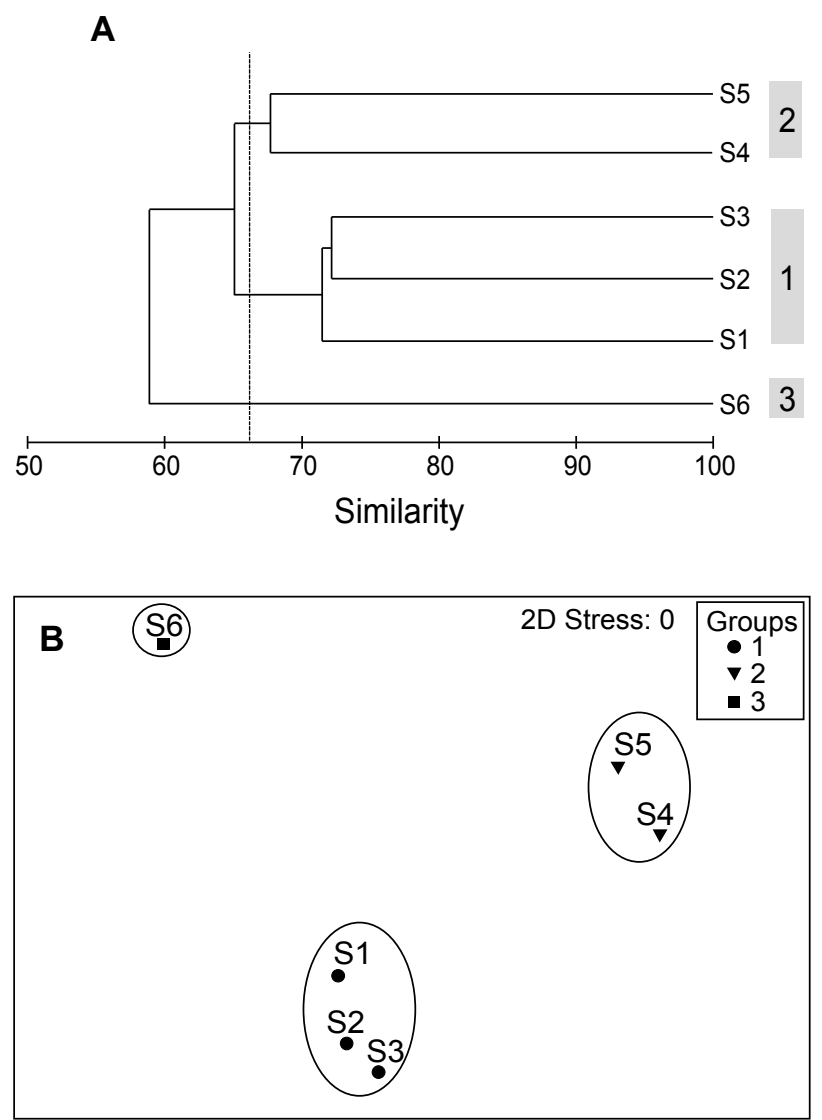

Fig. 2. Cluster analysis (A) and Non-metric Multi-Dimensional Scaling ordination plot (B) based on fish species abundance showing reciprocal relations between the six sampled stations in the Nador Lagoon, Morocco, according to Bray-Curtis similarity

- Group 2 (stations 4 and 5), and Group 3 (station 6)characterized by muddy bottom and the presence of macrophytes.

Station 6 is located across the lagoon from the marine inlet. Fish diversity and abundance were highest in group 1 stations (Fig. 3). At all stations, resident species (R) and benthivorous species (BV) were dominant in the fish assemblage in terms of both number of species and fish abundance (Fig. 4). However, omnivorous- (OV) and detritivorous (DV) species were also abundant in stations with vegetated bottom (groups 2 and 3 ).

Total fish abundance varied between 43 and 252 and was highest in spring and lowest in winter (Fig. 5). Fish diversity was highest in spring and summer (11 and 12 species, respectively) and lowest in autumn and winter ( 8 and 7 species, respectively). Shannon-Wiener diversity index varied from 1.24 in winter to 1.84 in summer. The most abundant fish species in the catches was the marbled goby, Pomatoschistus marmoratus (190 individuals, $34.63 \%$ of the total catches), followed by the sand smelt, Atherina presbyter Cuvier, 1829 (76 individuals, $13.82 \%$ of the total catches) and the broadnosed pipefish, Syngnathus typhle Linnaeus, 1758 (72 individuals, $13.21 \%$ of the total catches). Seven species represented more than $93 \%$ of the total abundance. These species showed seasonal abundance in the lagoon (Fig. 6). Poma-

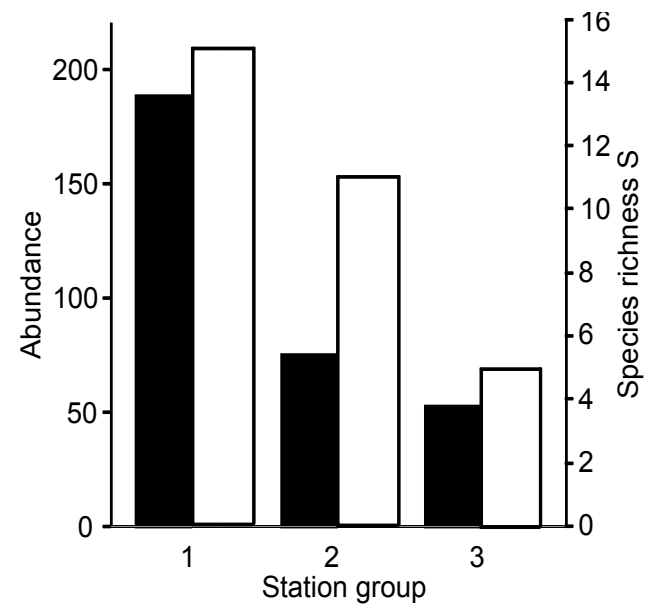

Fig. 3. Spatial variation in fish species richness and numerical abundance in the Nador Lagoon, Morocco, in three groups of stations: group 1 (stations 1, 2, and 3), group 2 (stations 4 and 5), and group 3 (station 6); Black bar $=$ fish abundance, white bar $=$ species richness

toschistus marmoratus, Syngnathus typhle, and Syngnathus abaster Risso, 1827 were mainly abundant during spring whereas Atherina presbyter, Hyporhamphus picarti, and Liza aurata (Risso, 1810) were abundant during autumn. Gobius niger Linnaeus, 1758 was abundant in winter and autumn.

In autumn, the fish assemblage was dominated by the marine juvenile migrants (A. presbyter and $H$. picarti) accounting for $69.7 \%$ of the total catches whereas in winter, spring, and summer, resident species dominated the assemblage $(65.7 \%$ to $85.4 \%$ of the total catches) (Fig. $7 \mathrm{~A})$. In autumn and winter, the fish assemblage was characterized by various feeding guilds. The feeding guilds were similar in spring and summer and were largely dominated by strictly benthivorous species (BV) accounting for $70.5 \%$ and $64 \%$ of the total catches, respectively, during spring and summer (Fig. 7B).

Factorial correspondence analysis (FCA) showed seasonal fish assemblages (Fig. 8A). Factors 1 and 2 (representing the first and second axes) explained $63.77 \%$ and $28.93 \%$ of the variance, respectively. Three groups appeared clearly on the graph:

- Group 1-autumn clearly separated into the positive part of axes 1 and 2 due to the presence of Dicentrarchus punctatus (Bloch, 1792), Hyporhamphus picarti, Atherina presbyter, Salaria pavo (Risso, 1810), and Liza aurata (Risso, 1810);

- Group 2-winter separated into the positive part of axis 1 and negative part of axis 2, characterized by the presence of the two species Gobius niger and Diplodus puntazzo (Walbaum, 1792); and

- Group 3-spring and summer separated into the negative parts of axis 1 and positive part of axis 2 , is characterised mainly by the presence of Solea solea (Linnaeus, 1758), Symphodus tinca (Linnaeus, 1758), Syngnathus abaster, S. typhle, Mullus barbatus Linnaeus, 1758, Symphodus cinereus (Bonnaterre, 1788), Pomatoschistus marmoratus, and Callionymus risso Lesueur, 1814. 

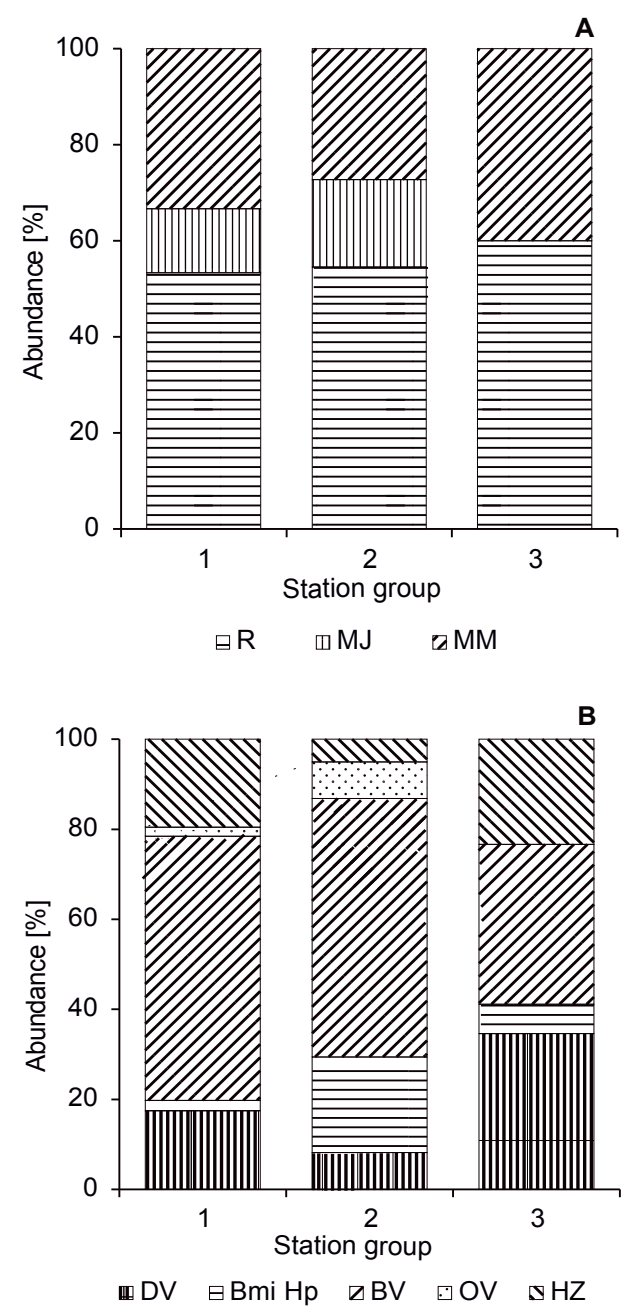

Fig. 4. Spatial variation in abundance of fish functional groups according to their habitat use and feeding modes in the Nador Lagoon, Morocco, in three groups of stations: group 1 (stations 1, 2, and 3), group 2 (stations 4 and 5), and group 3 (station 6); A: fish ecological groups: residents (R), marine seasonal migrants (MM) and marine juvenile migrants $(\mathrm{MJ})$; B: fish feeding groups: omnivorous (OV), strictly benthivorous (BV), detritivorous (DV), hyperbenthos-fish feeders (HZ), fish showing an ontogenetic change in feeding preference from hyperbenthos zooplankton to hyperbenthos (HZ, HP), fish showing an ontogenetic change in feeding preference from microbenthos to hyperbenthos (Bmi, HP)

Concerning the ecological guilds, a similar seasonal assemblage was also identified (Fig. 8B). Factors 1 and 2 explained more than $99 \%$ of total variance (54.76 and $44.15 \%$, respectively). The autumn group clearly separated into the positive part of axes 1 and 2 due to the dominance of the marine juvenile migrants $(\mathrm{MJ})$ and group of fish showing ontogenetic change preference from hyperbenthos zooplankton to hyperbenthos (HZ, HP). The winter group separated into the negative part of axis 1 and positive part of axis 2 was represented by MM species, omnivorous fish (OV), and fish showing an ontogenetic

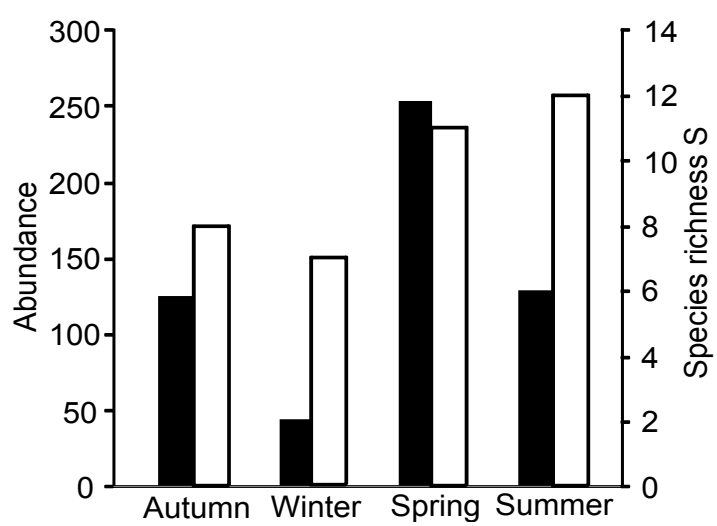

Fig. 5. Seasonal variation in fish species richness and numerical abundance in the Nador lagoon, Morocco; Black bar $=$ fish abundance, white $b a r=$ species richness

change in feeding preference from microbenthos to hyperbenthos (Bmi, HP). The spring-summer group was characterized mainly by the dominance of residents species (R) and strictly benthivorous- (BV) and hyperbenthos-fish feeders (HZ). The detritivorous feeding group (DV), represented by the single species Liza aurata located in the intermediate position between the groups ( 1 and 2 ) is common to the two groups. The SIMPER analysis showed a low similarity (mean 25\%) between the seasons (Table 2). Most of the dissimilarity between groups 1 (autumn) and 2 (winter) was due to two species, Hyporhamphus picarti and Atherina presbyter. Pomatoschistus marmoratus was the main species contributing in the dissimilarity between the group 3 (spring-summer) and the other seasons.

\section{DISCUSSION}

The Nador Lagoon is inhabited by a relatively abundant and diverse fish fauna. The fish species diversity in this lagoon was comparable to those described in other published studies undertaken in Mediterranean lagoons. For example, the fish species richness inventoried in the 40 Atlanto-Mediterranean lagoons studied by Pérez-Ruzafa et al. $(2007,2011)$ ranged between 6 and 48, with a mean of 23.4 species. In the southern Mediterranean region, the fish species diversity varied between 13 and 26 species: 19 species in Merja Zerga in Morocco, 26 in Ghar El Melh in Tunisia, 17 in Lake Manzala in Egypt (Kraïm et al. 2009), 13 in the Ichkeul Lagoon in Tunisia (Sellami et al. 2010). The records of commercial catches listed 38 species in the Mellah Lagoon, Algeria (Chaoui et al. 2006). Using a similar fishing gear, Bouchereau et al. (2000) recovered 18 species of fish from the Nador Lagoon.

Caution is needed when comparing fish diversity or assemblage structure in different ecosystems. Variations in observed fish diversity between lagoons might depend on the lagoon characteristics, the sampling effort, as well as the fishing gear type. For example, a higher sampling effort (measured here by the number of samples collected in the studies) usually allows a higher probability of capturing rare, or less abundant species, hence leading to an increase of the total number of species captured in the study (Krebs 1999). The beach seine net used is consid- 

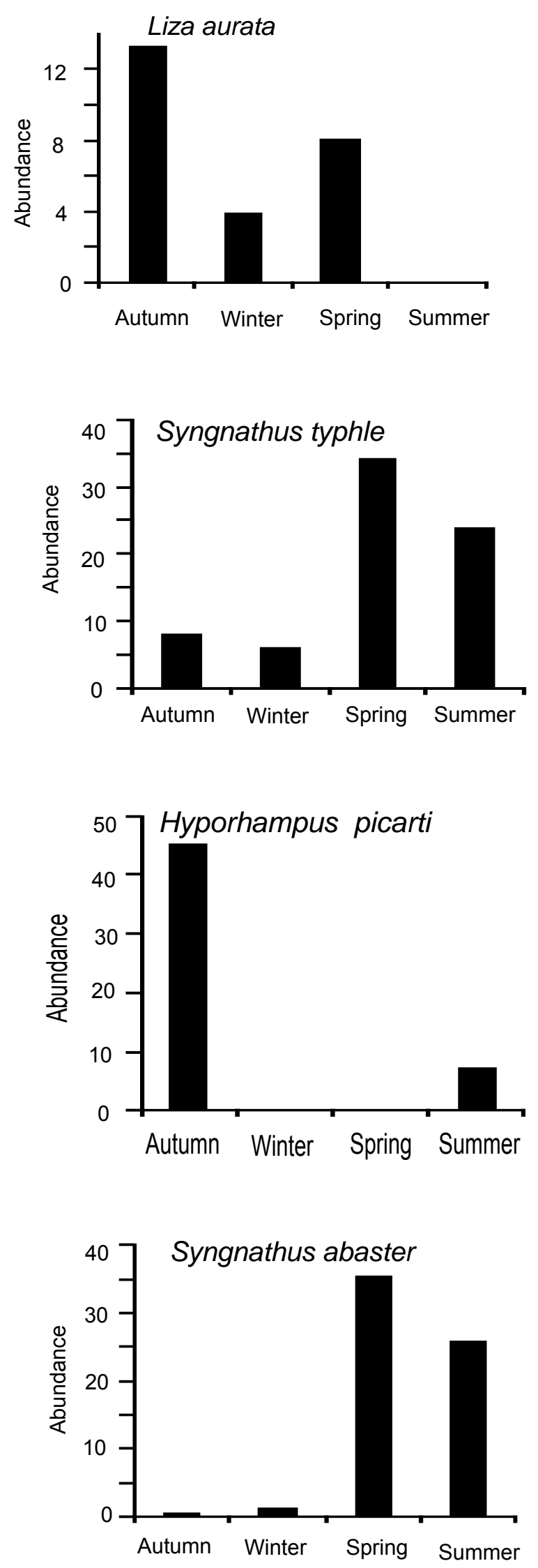
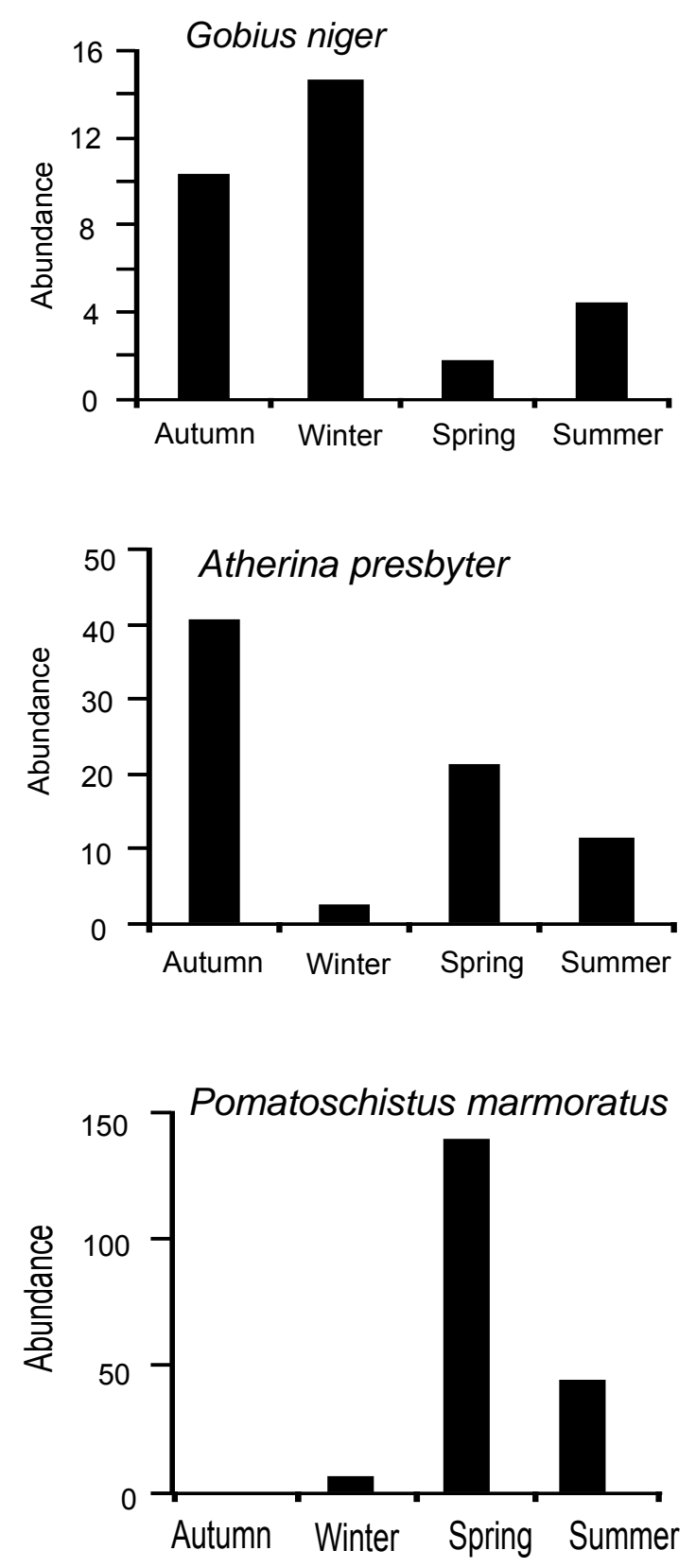

Fig. 6. Seasonal variation of the numerical abundance of the dominant fish species from the Nador Lagoon, Morocco 
ered to be a very effective technique for sampling in shallow waters, especially in lagoon ecosystems (Pierce et al. 1990, Franco et al. 2012).

As in many others lagoons, a small number of species dominated the assemblage (Maci and Basset 2009). The shallow water fish assemblages in the Nador Lagoon was dominated, in terms of fish abundance, by the marbled goby, Pomatoschistus marmoratus $34.63 \%$ of the total catches), followed by the sand smelt, Atherina presbyter $(13.82 \%$ of the total catches). Marbled goby is one of the dominant fish species in the shallow waters of the Mediterranean Sea (Verdiell-Cubedo et al. 2007). This small-bodied species can play an important role in trophic structure of the coastal shallow waters.

Three ecological groups were sampled in the shallow habitats of the Nador Lagoon according to species habitat use: residents $(\mathrm{R})$, including those species spawning in the
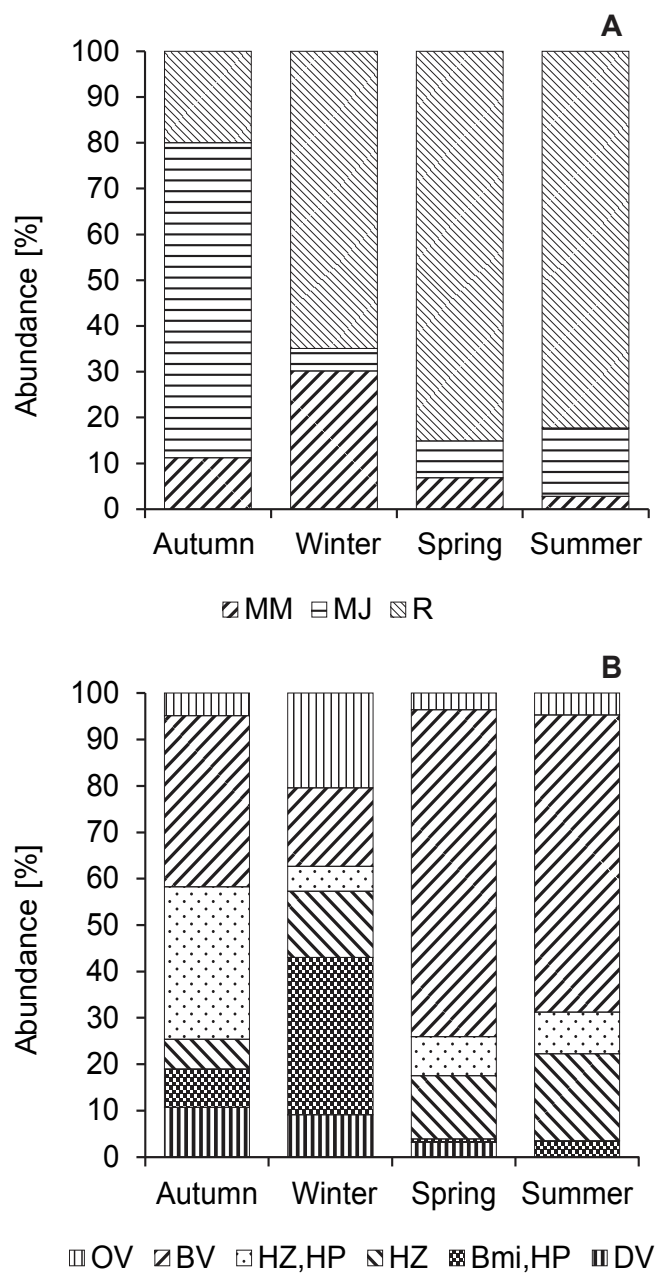

Fig. 7. Seasonal variation of functional groups of fish from the Nador Lagoon, Morocco according to their habitat use and feeding modes; $\mathbf{A}$ : fish ecological groups: residents (R), marine seasonal migrants (MM) and marine juvenile migrants (MJ); B: fish feeding groups: omnivorous $(\mathrm{OV})$, strictly benthivorous $(\mathrm{BV})$, detritivorous (DV), hyperbenthos-fish feeders (HZ), fish showing an ontogenetic change in feeding preference from hyperbenthos zooplankton to hyperbenthos (HZ, HP), fish showing an ontogenetic change in feeding preference from microbenthos to hyperbenthos (Bmi, HP)
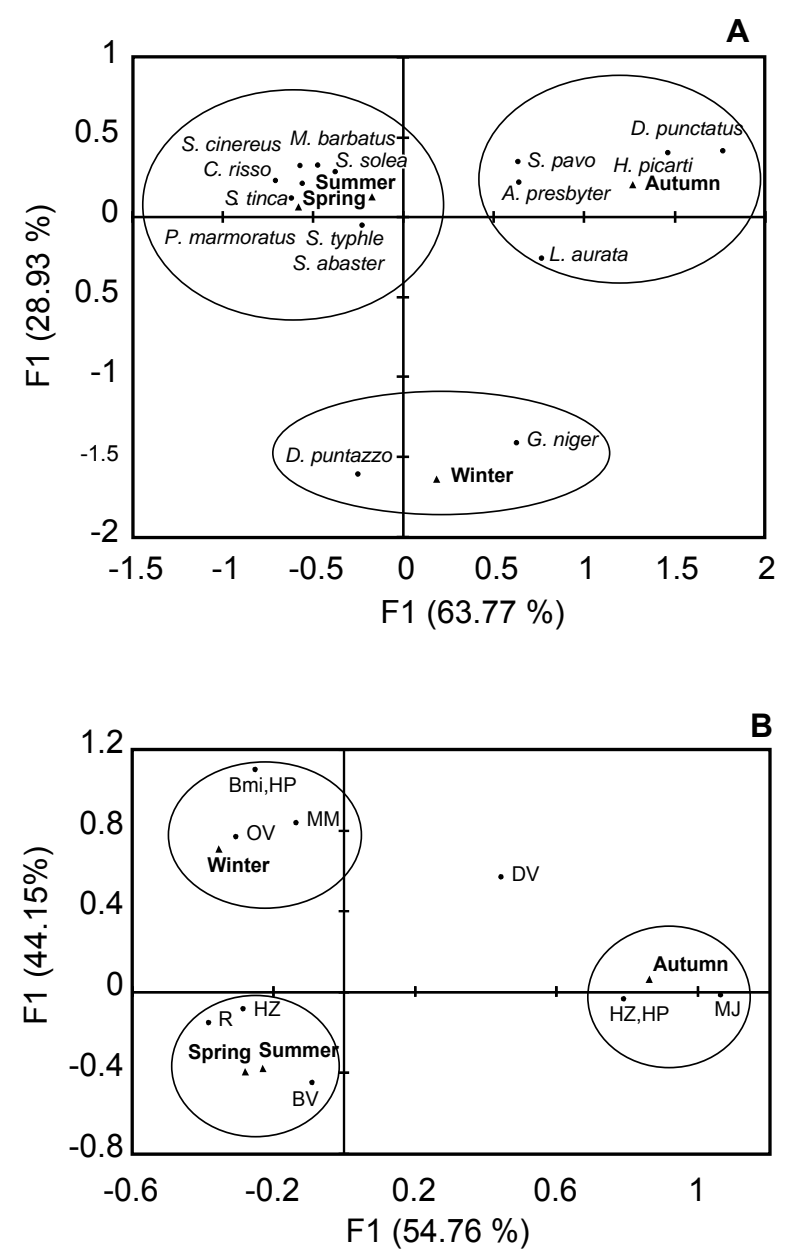

Fig. 8. Factorial correspondence analysis (FCA) performed using abundance (A) and ecological guild data (B) of fishes from the Nador Lagoon, Morocco; See Table 1 for species labels

lagoon, where they maintain stable populations; marine migrants (MM), including marine euryhaline species (i.e., spawning at sea) entering the lagoon on a regular basis mainly for feeding and shelter; marine juvenile migrants (MJ), which use the estuary primarily as a nursery ground, usually spawning and spending much of their adult life at sea but often returning seasonally to the estuary or lagoon (Elliott et al. 2007). In the presently reported study, the fish assemblage was largely dominated by the resident and benthivorous species representing, respectively, $68.43 \%$ and $57.14 \%$ of the total catches. In the SW Mediterranean, in the Mar Lagoon (Spain), an ecosystem with a comparably surface area $\left(135 \mathrm{~km}^{2}\right)$ also located in a semi-arid region, the majority of the fish taxa $(>50 \%)$ were resident in the lagoon (Franco et al. 2012). In this lagoon, benthivorous species (BV) were also dominant in the fish assemblage in terms of both species number and abundance. Similar fish assemblage in the Venice Lagoon was observed, with resident $(\mathrm{R})$ group being the most represented, both in number of species and fish abundance (Malavasi et al. 2004, Franco et al. 2006).

These results contrast with many other studies conducted in European lagoons. Franco et al. (2008) showed that fish assemblages from 19 northern Mediterranean lagoons 
were dominated in general by marine species and detritivorous and omnivorous fish. However such difference in ecological guild may result from the relatively harsher and variable conditions in northern lagoons excluding many marine fish, especially marine stenohaline species, from permanent residency in these systems as suggested by McLusky and Elliott (2004) for estuarine species.

The connection with the sea (mouth configuration: width and area) was showed to be an important factor related to the number of fish species in a lagoon (Perez-Ruzafa et al. 2007, Franco et al. 2008). The short distance from the marine inlets may explain the higher abundance and total number of species recorded in group 1, being consistent with the observation that the short distance from the marine inlets tends to increase the fish biodiversity and abundance (Gordo and Cabral 2001, Malavasi et al. 2004). Stations from groups 2 and 3 were also affected by fresh water influx. In spite of these differences, the fish assemblage composition of the three groups, in terms of both their ecological and dietary preference guilds, were not very different. These results contrast with other studies conducted in northern Europe where vegetated habitat generally supports more diverse fauna due to the higher complexity of this habitat providing higher food availability and refuge from predators (Malavasi et al. 2004, Franco et al. 2006).

The fish assemblages differed markedly among seasons both in terms of fish abundance and diversity and also in terms of functional guilds composition. In contrast with studies conducted in northern Mediterranean lagoons where abundance was higher in mid-summer, with a second peak in autumn (Koutrakis et al. 2000, Akin et al. 2005, Franco et al. 2006, Maci and Basset 2009), fish abundance peaked in spring and species diversity was higher in spring and summer. In autumn, fish assemblage was dominated by the marine juvenile migrants (Atherina presbyter and Hyporhamphus picarti) accounting for $86 \%$ of the total catches. This confirmed importance of lagoon as nursery habitats for juvenile marine fish as reported by many authors (Malavasi et al. 2004, Franco et al. 2006, Maci and Basset 2009). In winter, spring, and summer, resident species constituted the most abundant ecological guild in the lagoon as described in other lagoons (Akin et al. 2005, Franco et al. 2006). The resident species dominating the fish assemblages in the Nador Lagoon were mostly represented by the marbled goby Pomatoschistus marmoratus and the syngnathids - Syngnathus typhle and S. abaster.

In autumn and winter, the fish assemblage was characterized by various feeding guilds. This can be ascribed to the seasonality of the colonization of lagoon environment by marine migrant and marine juvenile species. The feeding guilds were similar in spring and summer and were largely dominated by strictly benthivorous species (BV) accounting for $70.5 \%$ and $64 \%$ of the total catches, respectively. Such seasonal variation in fish assemblage was described in many lagoons (Franco et al. 2006, Maci and Basset 2009).

In conclusion, the shallow water fish assemblage in the Nador Lagoon was dominated, in terms of fish abundance, by a small number of species, the most abundant of them being the marbled goby, Pomatoschistus marmoratus. In the presently reported study, the combination of a taxonomic and functional description of the fish assemblage permits a better understanding of their functioning. A clear seasonal use of the lagoon was determined. In winter, spring, and summer, the fish assemblage was dominated by resident species whereas in autumn, the marine juvenile migrants became predominant. The latter group is attracted by the relative predation sheltering as well as by the food availability caused by high productivity. Consequently their survival and growth are enhanced. Species may also use these habitats in search of an optimum physiological environment that promotes maximal growth. Stations located near the marine inlet (group 1) showed the highest fish diversity and abundance suggesting a major nursery role of

Table 2

Discrimination of fish species from the Nador Lagoon, Morocco, based on percentage contribution, of each seasonal group, defined by SIMPROF test, using SIMPER analysis

\begin{tabular}{lccccc}
\hline \multicolumn{1}{c}{ Species } & \multirow{2}{*}{ Habitat use } & Feeding mode & $\begin{array}{c}\text { Groups } \\
1 \text { and 2 }\end{array}$ & $\begin{array}{c}\text { Groups } \\
1 \text { and 3 }\end{array}$ & $\begin{array}{c}\text { Groups } \\
2 \text { and 3 }\end{array}$ \\
\hline Liza aurata & $\mathrm{MM}$ & $\mathrm{DV}$ & 7.76 & 4.47 & - \\
Hyporhamphus picarti & $\mathrm{MJ}$ & $\mathrm{BV}$ & 37.50 & 18.19 & - \\
Atherina presbyter & $\mathrm{MJ}$ & $\mathrm{HZ}, \mathrm{HP}$ & 31.72 & 11.21 & 7.59 \\
Diplodus puntazzo & $\mathrm{MM}$ & $\mathrm{OV}$ & 7.30 & - & 3.11 \\
Salaria pavo & $\mathrm{R}$ & $\mathrm{OV}$ & 4.96 & - & - \\
Pomatoschistus marmoratus & $\mathrm{R}$ & $\mathrm{BV}$ & 4.96 & 36.62 & 43.60 \\
Syngnathus abaster & $\mathrm{R}$ & $\mathrm{BV}$ & - & 12.93 & 16.75 \\
Syngnathus typhle & $\mathrm{R}$ & $\mathrm{HZ}$ & - & - & 12.85 \\
Gobius niger & $\mathrm{R}$ & $\mathrm{Bmi}, \mathrm{HP}$ & - & 74.55 & 6.65 \\
Average dissimilarity [\%] & & & 72.05 & 77.51 \\
\hline
\end{tabular}

$\mathrm{MM}=$ marine seasonal migrants, $\mathrm{MJ}=$ marine juvenile migrants, $\mathrm{R}=$ resident, $\mathrm{DV}=$ detritivorous, $\mathrm{BV}=$ benthivorous, $\mathrm{HZ}, \mathrm{HP}=\mathrm{fish}$ showing an ontogenetic change in feeding preference from hyperbenthos zooplankton to hyperbenthos, $\mathrm{OV}=$ omnivorous, $\mathrm{HZ}=$ hyperbenthos fish feeders, $\mathrm{Bmi}, \mathrm{HP}=$ fish showing an ontogenetic change in feeding preference from microbenthos to hyperbenthos. 
this habitat with respect to the other shallow water habitats investigated. The combination of environmental parameters in future analysis should allow better explanation of the spatial and seasonal patterns of the fish assemblages.

\section{ACKNOWLEDGEMENTS}

This work was produced with the support of the Franco-Moroccan Committee (Integrated Moroccan-French Action No. MAG/12/02), which is gratefully acknowledged. Thanks to Denis Marin (LOG UMR8187) for his help in the figure editing.

\section{REFERENCES}

Akin S., Buhan E., Winemiller K.O., Yilmaz H. 2005. Fish assemblage structure of Koycegiz Lagoon-Estuary, Turkey: Spatial and temporal distribution patterns in relation to environmental variation. Estuarine, Coastal and Shelf Science 64 (4): 671-684. DOI: $10.1016 /$ j.ecss.2005.03.019

Bouchereau J.-L., Guelorget O., Vergne Y., Perthuisot J.-P. 2000. L'ichtyofaune dans l'organisation biologique d'un système paralique de type lagunaire: Le complexe des étangs du Prévost et de l'Arnel (Languedoc, France). Vie et milieu 50 (1): 19-27.

Chaoui L., Kara M.H., Faure E., Quignard J.-P. 2006. L'ichtyofaune de la lagune du Mellah (Algérie NordEst): diversité, production et analyse des captures commerciales. Cybium 30 (2): 123-132.

Clarke K.R., Warwick R.M. 2001. Change in marine communities; An approach to statistical analysis and interpretation. 2nd edn. Primer- E, Plymouth, UK.

Crivelli A.J., Ximenes M.C. 1992. Alterations to the functioning of Mediterranean lagoons and their effects on fisheries and aquaculture. Pp. 134-140. In: Finlayson M., Hollis T., Davis T. (eds.) Managing Mediterranean wetlands and their birds. IWRB Special Publication No. 20, Slimbridge, UK.

Dumay O., Tari P.S., Tomasini J.A., Mouillot D. 2004. Functional groups of lagoon fish species in Languedoc Roussillon, southern France. Journal of Fish Biology 64 (4): 970-983. DOI: $10.1111 / \mathrm{j} .1095-8649.2004 .00365 . \mathrm{x}$

Elliott M., Hemingway K. 2002. Fishes in estuaries. Blackwell Science, Oxford, UK. DOI: $10.1002 / 9780470995228$

Elliott M., Quintino V. 2007. The estuarine quality paradox, environmental homeostasis and the difficulty of detecting anthropogenic stress in naturally stressed areas. Marine Pollution Bulletin 54 (6): 640-645. DOI: 10.1016/j.marpolbul.2007.02.003

El Madani F., Chiaar A., Chafi A. 2011. Phytoplankton composition and abundance assessment in the Nador Lagoon (Mediterranean coast of Morocco). Acta Botanica Croatica 70 (2): 269-288.

Franco A., Franzoi P., Malavasi S., Riccato F., Torricelli P. 2006. Fish assemblages in different shallow water habitats of the Venice Lagoon. Hydrobiologia 555 (1): 159-174.

DOI: $10.1007 / \mathrm{s} 10750-005-1113-5$
Franco A., Franzoi P., Torricelli P. 2008. Structure and functioning of Mediterranean lagoon fish assemblages: A key for the identification of water body types. Estuarine, Coastal and Shelf Science 79 (3): 549-558. DOI: 10.1016/j.ecss.2008.05.011

Franco A., Pérez-Ruzafa A., Drouineau H., Franzoi P., Koutrakis E.T., Lepage M., Verdiell-Cubedo D., Bouchoucha M., López-Capel A., Riccato F., Sapounidis A., Marcos C., Oliva-Paterna F.J., Torralva-Forero M., Torricelli P. 2012. Assessment of fish assemblages in coastal lagoon habitats: Effect of sampling method. Estuarine, Coastal and Shelf Science 112: $115-125$.

DOI: $10.1016 /$ j.ecss.2011.08.015

Froese R., Pauly D. (eds.) 2014. FishBase. [version 11/2014] www.fishbase.org

Gordo L.S., Cabral H.N. 2001. The fish assemblage structure of a hydrologically altered coastal lagoon: the Obidos Lagoon (Portugal). Hydrobiologia 459 (1-3): 125-133. DOI: $10.1023 / \mathrm{A}: 1012510608231$

Guelorget O., Perthuisot J.-P., Frisoni G.-F., Monti D. 1987. Le rôle du confinement dans l'organisation biogéologique de la lagune de Nador (Maroc). Oceanologica Acta 10 (4): 435-444.

Guest M.A., Connolly R.M., Loneragan N.R. 2003. Seine nets and beam trawls compared by day and night for sampling fish and crustaceans in shallow seagrass habitat. Fisheries Research 64 (2-3): 185-196. DOI: $10.1016 / \mathrm{S} 0165-7836(03) 00109-7$

Kada O., Abdellaoui S., Ramdani M., Nachit D. 2009. Contribution à l'identification et à la caractérisation biologique et dynamique de l'anchois de la lagune de Nador (Maroc). Bulletin de l'Institut Scientifique, Rabat, section Sciences de la Vie 31 (2): 91-98.

Koutrakis E.T., Kokkinakis A.A., Eleftheriadis E.A., Argyropoulou M.D. 2000. Seasonal changes in distribution and abundance of the fish fauna in the two estuarine systems of Strymonikos Gulf (Macedonia, Greece). Belgian Journal of Zoology 130: 41-48.

Kraïem M.M., Chouba L. Ramdani M. Ahmed M.H., Thompson J.R., Flower R.J. 2009. The fish fauna of three North African lagoons: specific inventories, ecological status and production. Hydrobiologia 622: 133-146. DOI: $10.1007 / \mathrm{s} 10750-008-9679-3$

Krebs C.J. 1999. Ecological methodology. 2nd edn. Addison-Welsey Educational Publishers, Menlo Park, CA, USA.

Kruskal J.B., Wish M. 1978. Multidimensional scaling. Sage Publications, Thousand Oaks, CA, USA.

Maci S., Basset A. 2009. Composition, structural characteristics and temporal patterns of fish assemblages in non-tidal Mediterranean lagoons: A case study. Estuarine, Coastal and Shelf Science 83 (4): 602-612. DOI: 10.1016/j.ecss.2009.05.007

Malavasi S., Fiorin R., Franco A., Franzoi P., Granzotto A., Riccato F., Mainardi D. 2004. Fish assemblages of Venice Lagoon shallow waters: An analysis 
based on species, families and functional guilds. Journal of Marine Systems 51 (1-4): 19-31.

DOI: $10.1016 /$ j.jmarsys.2004.05.006

McLusky D.S., Elliott M. 2004. The estuarine ecosystem: ecology, threats and management. 3rd edn. Oxford University Press, Oxford, UK.

Pérez-Ruzafa A., Marcos C. 2012. Fisheries in coastal lagoons: An assumed but poorly researched aspect of the ecology and functioning of coastal lagoons. Estuarine, Coastal and Shelf Science 110: 15-31. DOI: 10.1016/j.ecss.2012.05.025

Pérez-Ruzafa A., Marcos C., Pérez-Ruzafa I.M. 2011. Mediterranean coastal lagoons in an ecosystem and aquatic resources management context. Physics and Chemistry of the Earth 36 (5-6): 160-166. DOI: $10.1016 /$ j.pce.2010.04.013

Pérez-Ruzafa A., Monpeán C., Marcos C. 2007. Hydrographic, geomorphologic and fish assemblage relationship in coastal lagoons. Hydrobiologia 577 (1): 107-125.

DOI: $10.1007 / \mathrm{s} 10750-006-0421-8$

Pierce C.L., Rasmussen J.B., Leggett W.C. 1990. Sampling littoral fish with a seine: Corrections for variable capture efficiency. Canadian Journal of Fisheries and Aquatic Sciences 47 (5): 1004-1010.

DOI: $10.1139 / \mathrm{f03}-098$
Poizat G., Rosecchi E., Chauvelon P., Contournet P., Crivelli A.J. 2004. Long-term fish and macro-crustacean community variation in a Mediterranean lagoon. Estuarine, Coastal and Shelf Science 59 (4): 615-624. DOI: 10.1016/j.ecss.2003.11.007

Ruiz F., Abad M., Olías M., Galán E., González I., Aguilá E., Hamouni N., Pulido I., Cantano M. 2006. The present environmental scenario of the Nador Lagoon (Morocco). Environmental Research 102 (2): 215229.

DOI: $10.1016 /$ j.envres.2006.03.001

Sellami R., Chaouachi B., Ben Hassine O.K. 2010. Impacts anthropiques et climatiques sur la diversité ichtyque d'une lagune méditerranéenne (Ichkeul, Tunisie). Cybium 34 (1): 5-10.

Verdiell-Cubedo D., Oliva-Paterna F.J., Torralva M. 2007. The effects of competitors on fitness of marbled goby Pomatoschistus marmoratus (Pisces: Gobiidae) in the Mar Menor coastal lagoon (SE Iberian Peninsula). Italian Journal of Zoology 74 (2): 169-177. DOI: $10.1080 / 11250000701202081$

Received: 14 September 2014 Accepted: 1 February 2015 Published electronically: 30 June 2015 